Revue d'histoire de l'Amérique française

FBS REVUE D.HISTOIRE DE L'AMÉRIQUE FRANÇAISE

\title{
Jean Nicolet au lac Michigan : histoire d'une erreur historique
}

Jacques Gagnon

Volume 50, numéro 1, été 1996

URI : https://id.erudit.org/iderudit/305490ar

DOI : https://doi.org/10.7202/305490ar

Aller au sommaire du numéro

Éditeur(s)

Institut d'histoire de l'Amérique française

ISSN

0035-2357 (imprimé)

1492-1383 (numérique)

Découvrir la revue

Citer cette note

Gagnon, J. (1996). Jean Nicolet au lac Michigan : histoire d'une erreur historique. Revue d'histoire de l'Amérique française, 50(1), 95-101.

https://doi.org/10.7202/305490ar d'utilisation que vous pouvez consulter en ligne.

https://apropos.erudit.org/fr/usagers/politique-dutilisation/ 


\title{
NOTE DE RECHERCHE
}

\section{JEAN NICOLET AU LAC MICHIGAN HISTOIRE D'UNE ERREUR HISTORIQUE}

\author{
JACQUES GAGNON \\ Collège de Sherbrooke
}

\section{INTRODUCTION}

Jean Nicolet est le premier Blanc qui ait habité à l'île-auxAllumettes sur la rivière Outaouais et au lac Nipissing qui se déverse dans le lac Huron. Il est aussi l'un des premiers Européens à franchir le Sault Sainte-Marie et à naviguer sur le lac Supérieur. Pourtant, presque rien ne rappelle son souvenir en Ontario alors qu'il a sa statue à Green Bay (lac Michigan, Wisconsin) où il n'a jamais mis le pied... Depuis les articles de Wilson ${ }^{1}$, Dever ${ }^{2}$ et Trudel $^{3}$, la vérité historique a graduellement été rétablie. Pas toujours, cependant, puisqu'on retrouve encore cette erreur dans l'Atlas historique du Canada ${ }^{4}$.

Là n'est toutefois pas notre propos. Notre objectif est plutôt de voir comment s'est construite l'erreur historique à son origine même. Nous verrons d'abord la contribution involontaire de l'historien américain Edmund B. O'Callaghan à cette affaire. Puis la «découverte» par John G. Shea de l'expédition de Nicolet au Michigan et l'aval donné à cette «découverte» par de prestigieux historiens contem-

1. Clifford P. Wilson, «Where Did Nicolet Go?», Minnesota History, 37,3 (septembre 1946): 216-220.

2. Harry Dever, «The Nicolet Myth», Michigan History, 50,4 (décembre 1966): 318322.

3. Marcel Trudel, «Jean Nicollet dans le lac Supérieur et non dans le lac Michigan», Revue d'histoire de l'Amérique francaise, 34,2 (septembre 1980): 183-196. Repris dans le volume III, tome 2 de son Histoire de la Nouvelle-France (Montréal, Fides, 1983), 217-225.

4. Richard I. Ruggles et Conrad E. Heidenreich, «Explorations françaises», R. Cole Harris, dir., Atlas historique du Canada, I: Des origines à 1800 (Montréal, Presses de l'Université de Montréal, 1987), planche 36. 
porains. Enfin, nous nous attarderons aux notes infrapaginales de John G. Shea pour recenser les autres erreurs de son texte et la source de ces erreurs. Comme nous faisons ni plus ni moins que de l'archéologie littéraire, on ne se surprendra pas de retrouver de longues citations textuelles dans les pages qui suivent.

\section{LA CONTRIBUTION D'EDMUND BAILY O'CALLAGHAN}

$\mathrm{Au}$ milieu du $\mathrm{XIX}^{\mathrm{e}}$ siècle, les historiens nord-américains se remettent à lire les Relations des Jésuites, plus ou moins oubliées depuis la fin du $\mathrm{XVII}^{\mathrm{e}}$ siècle. Ils y trouvent une mine de renseignements inépuisable sur les premières explorations européennes du nord-est du continent, sur la période de contact entre Blancs et Amérindiens et sur les rivalités entre Français, Hollandais et Britanniques.

Parmi ces historiens se distingue Edmund B. O'Callaghan, médecin d'Albany, État de New York. Originaire d'Irlande, celui-ci a d'abord émigré au Bas-Canada où il se fait élire député patriote du comté de Yamaska et devient le bras droit de Papineau. Contraint à l'exil aux États-Unis, avec l'échec de la Rébellion de 1837, O'Callaghan conserve néanmoins des contacts à Montréal, dont le père Félix Martin, jésuite, fondateur du Collège Sainte-Marie et historien de sa compagnie $^{5}$. En 1847, O'Callaghan publie à la Société historique de New York une étude de 22 pages intitulée Jesuit Relations of Discoveries and Other Occurrences in Canada and the Northern and Western States of the Union (1632-1672). À la page 5 de cette étude, O'Callaghan écrit:

Within seven years of their second arrival [in 1632, the Jesuits] had completed the examination of the country from Lake Superior to the gulf, and founded several villages of Christian neophytes on the borders of the upper lakes. While the intercourse of the Dutch was yet confined to the Indians in the vicinity of Fort Orange, and «five years before Elliott of New England had addressed a single word to the Indians within six miles of Boston harbor the French missionaries planted the cross at Sault St. Marie», whence they looked down on the Sioux country and the valley of the Mississippi. The vast and unknown West now opened its prairies before them; the Wisconsin and Fox Rivers are discovered.

O'Callaghan rédige ensuite la biographie des premiers supérieurs jésuites qu'il termine avec le père Claude Dablon présenté, à tort,

5. Jacques Monet, «O'Callaghan, Edmund Bailey», Dictionnaire biographique du Canada (Québec/Toronto, Presses de l'Université Laval/University of Toronto Press, 1972), X: 608-609. 
comme missionnaire chez les Winnebagoes du Wisconsin à partir de $1671^{6}$. En 1848, il est nommé archiviste de l'État de New York. Deux ans plus tard, son étude sur les Jésuites est traduite en français par le père Martin et ses biographies des supérieurs de la compagnie sont reprises en 1858 dans l'introduction à la première édition nord-américaine des Relations, chez Augustin Côté à Québec ${ }^{7}$. C'est dire l'importance qu'on accorde à l'époque à sa contribution historique.

\section{LA «DÉCOUVERTE»DE JOHN GILMARY SHEA}

John G. Shea est lui aussi un Américain d'origine qui a séjourné au Québec. Né à New York et diplômé en droit de Columbia, il entre au noviciat des Jésuites et déménage au Collège Sainte-Marie de Montréal en 1850. C'est à Montréal qu'il devient un disciple du père Félix Martin, grâce à qui il entre en contact avec O'Callaghan qui restera un ami de Shea pour la vie. En 1852, Shea quitte les Jésuites et reprend sa carrière de droit à New York. Plus tard, il deviendra éditeur de divers magazines catholiques et consacrera le reste de son existence à sa nouvelle vocation au point de mériter le titre de «père de l'histoire du catholicisme américain ${ }^{8}{ }$. Mais, déjà en 1852 , notre apprenti historien publie son Discovery and Exploration of the Mississippi Valley with the Original Narratives of Marquette, Membré, Hennepin, and Anastase Douay ${ }^{9}$ où il reprend de façon intégrale des passages d'O'Callaghan.

Comment Shea fut-il amené à «découvrir» l'expédition de Nicolet au lac Michigan et dans l'actuel Wisconsin? En corrigeant et en ajoutant au texte d'O'Callaghan. Dans le passage précité, il remplace «seven years» par «ten years» et «Sault St. Marie» par «Sault Ste. Marie» (p. xx). De plus, il omet la dernière phrase: «the Wisconsin and Fox Rivers are discovered». Mais nous verrons que c'est pour introduire Nicolet en lieu et place des Jésuites. Retournons donc au texte de Shea:

6. Edmund Bailey O'Callaghan, Jesuit Relations of Discoveries and Other Occurrences in Canada and the Northern and Western States of the Union (1632-1672) (New York, Press of the Historical Society, 1847), 22 p. L'erreur de O'Callaghan nous a été signalée par un des évaluateurs de la $R H A F$ qui nous mentionne en outre que les Jésuites n'ont pas complété leur exploration au lac Supérieur en 1639

7. Anonyme, Relations des Jésuites (1611-1672) (Québec, chez Augustin Côté, 1858), 3 volumes.

8. Joseph P. Donnelly, Thwaites' Jesuit Relations and Allied Documents Errata and Addenda (Chicago, Loyola University Press, 1967), 269 p.

9. John Gilmary Shea, Discovery and Exploration of the Mississippi Valley (Redfield, New York, 1852), xx-xxii. 
In the history of the French colonies, [the Jesuit Relations] are a source such as no other part of the country possesses. For our present purpose, they have been invaluable; from them we can trace step by step, the gradual discovery of the Mississippi.

As early as 1639 , the adventurous and noble hearted sieur Nicolet, the interpreter of the colony had struck west of the Hurons, and, reaching the last limits of the Algonquins, found himself among the Ouinipegou (Winnebagoes), «a people called so, because they came from a distant sea, but whom some French erroneously called Puants» says [the Jesuit Relations]. Like the Nad8e8is they spoke a language distinct from the Huron and Algonquin. With these Nicolet entered into friendly relations, and exploring Green bay, ascended Fox river to his portage, and embarked on a river, flowing west; and says Father Vimont [en fait, il s'agit du père Le Jeune], «the sieur Nicolet who had penetrated furthest into those distant countries, avers that had he sailed three days more on a great river which flows from that lake (Green bay), he would have found the sea». This shows that Nicolet [...] mistook for the sea the Indian term Great Water, applied to the Mississippi. It is certain then, that to Nicolet is due the credit of having been the first to reach the waters of the Mississippi (p. xx-xxi).

C'est ainsi que Shea substitue Nicolet aux Jésuites d'O'Callaghan dans la découverte du pays sioux et de la vallée du Mississipi... découverte qu'O'Callaghan avait d'ailleurs largement anticipée dans son texte! Mais les autres historiens contemporains ont-ils fait preuve de plus de prudence? On trouve d'abord François-Xavier Garneau qui, dans la troisième édition revue et augmentée de son Histoire du Canada $^{10}$ mentionne Nicolet et sa supposée exploration du lac Michigan en 1639. Quant à l'abbé Ferland ${ }^{11}$ et à Francis Parkman ${ }^{12}$, ils citent explicitement les pages de Shea dès leur première édition et dans les éditions subséquentes. Que ces historiens soient Canadiens ou Américains, catholiques ou protestants, libéraux ou conservateurs, ils sont tous tombés sous le charme de notre Irlandais américain francophile et trop bon conteur. Malgré le fait qu'ils disposaient de la toute récente réédition des Relations des Jésuites à Québec en 1858 et qu'ils pouvaient facilement vérifier les assertions de Shea... 226.

10. François-Xavier Garneau, Histoire du Canada (Québec, Lamoureux, 1859), I: 224 et

11. Jean-Baptiste Ferland, Cours d'histoire du Canada (Québec, Augustin Côté, 1861), 325.

12. Francis Parkman, The Jesuits in North America in the XVIIth Century (1866), 166. 


\section{LES NOTES INFRAPAGINALES DE JOHN G. SHEA}

Dans deux notes au bas des pages xx à xxii, Shea rédige la biographie de Nicolet et fait l'étymologie du lac des Puants et du lac Winnipeg à partir des Relations de 1640 et de 1643, ainsi que du résumé de Creuxius ${ }^{13}$. (Ce jésuite français, François Du Creux, avait été chargé par ses supérieurs de rédiger en latin un résumé officiel des Relations pour l'édification des classes éduquées en 1664...)

As we are perhaps the first to advance the claim of the sieur Nicolet, it may not be amiss to give a meager sketch of a man too much unknown, though he occupied an important place in the early history of Canada. He came out to Canada in 1618, and was never from that time unemployed. Almost immediately after his coming, he was sent to the plundering Honqueronons, or Indians of the island, above the Chaudiere falls on the Ottawa. Here he remained two years... After this, he was sent with four hundred Algonquins to make peace with the Iroquois, and completely succeeded in his mission. He was then for eight or nine years stationed among the Nipissings, and became almost as Indian as they. After the restoration of Canada to France, he was made interpreter and commissary of the colony, which office he filled till he was sent, about 1639 , to Green Bay, and the Men of the Sea, where he met an assembly of four or five thousand men, and concluded peace with them. It must have been at this time that he ascended the Fox river to the Wisconsin. Returning to Quebec, he succeeded Olivier as commissary, and retained this office till his death. In 1641, we found him with F. Ragueneau, negotiating a peace with the Iroquois, at Three-Rivers. In 1642, sent from Quebec to Three-Rivers, to rescue a poor Abenaqui from the hands of some pagan Algonquins, he set out in a small boat on the 31st of October, at sunset with Savigni, but a storm came on, and their little craft capsized near Sillery... Thus perished, in a work of Christian charity, the sieur Nicolet, the first Frenchman who reached the waters of the Mississippi. See Rel.1639-'40, p. 135. Rel.1640-'41, ch. IX. Rel.1642-'43, p. 8. Creuxius, p. 359.

Rel.1639-'40, p. 132,135, etc. The Lac des Puants is laid down on Champlain's map of 1632; but in all probability, only from report, as it is placed north of Lake Superior, unless it is meant for Lake Winnipeg, which like Green bay, got his name from the Algonquin epithet for the Dacotahs, as coming from the Pacific.

13. François Du Creux, alias Creuxius, Historiae canadensis, seu Novae-Franciae (Paris, Cramoisy, 1664). Traduit en anglais par The Champlain Society, The History of Canada or New France (Toronto, 1951-1952), 2 vol. 
Mentionnons les erreurs factuelles commises par Shea dans ses notes en nous référant à ses sources et à des chercheurs plus récents:

1 - Nicolet n'est pas arrivé au Canada en 1618 mais en 1619 (erreur de la Relation de 1643 relevée par Trudel).

2 - L'ambassade de Nicolet auprès des Iroquois avec un groupe d'Algonquins n'a pas eu lieu après son séjour chez les Indiens de l'île mais pendant ce séjour, selon la Relation de 1643.

3 - L'expédition de Nicolet ne put avoir lieu en 1639 puisque sa présence dans la colonie est attestée de 1635 à 1642 (erreur relevée par Sulte).

4 - Nicolet n'a pas succédé à son beau-frère Olivier Letardif comme commis général à Québec, mais il le remplaçait à titre temporaire (erreur de Creuxius reprise par Shea).

5 - Le prisonnier que Nicolet est appelé à délivrer en 1642 n'est pas un Abénaqui mais un Sokoki, d'une nation voisine des Abénaquis (erreur de Creuxius reprise par Shea).

6 - Savigni est en fait François Berchereau de Chavigny (erreur de la Relation de 1643 reprise par Shea).

7 - Nicolet n'est pas mort le 31 octobre 1642 puisqu'il apparaît le 29 octobre au registre des sépultures de Notre-Dame de Québec (erreur de la Relation de 1643 reprise par Shea. Remarquons que Trudel fait lui aussi erreur à propos de ce décès qu'il situe en novembre...).

8 - Et, bien sûr, Nicolet n'a jamais atteint le Mississipi! La Relation de 1640 ne dit pas que Nicolet s'est embarqué sur une rivière coulant vers l'ouest, contrairement à Shea, mais que s'il «eust vogué trois jours plus avant sur un grand fleuve qui sort de ce lac [...] il auroit trouvé la mer».

9 - Winnipeg ne signifie pas en langue algonquine océan Pacifique mais eau puante (salée), toujours selon la Relation de 1640. C'est la même signification pour les rivières et lacs ontariens Nipigon (selon Trudel) et Wenebegon (selon Dever).

Mais peut-on imputer tous les torts à John G. Shea? Rappelons que la moitié de ses erreurs factuelles lui vient des Relations et de la Historiae Canadensis, seu Novae-Franciae de Creuxius...

\section{CONCLUSION}

Dans les pages qui précèdent, nous n'avons pas voulu diminuer la responsabilité de John G. Shea dans la création de la légende de 
Nicolet au lac Michigan. Comme il l'écrivait lui-même: «We are perhaps the first to advance the claim of the sieur Nicolet.» (p. xx) Mais il n'est pas le dernier, loin de là! Outre ses célèbres contemporains (Garneau, Ferland et Parkman), on doit ajouter pour les décennies qui suivent les auteurs cités par Trudel (Sulte, Butterfield, Thwaites et Gosselin). Et encore dans les années 1980 et 1990, on ne compte pas les atlas historiques, dictionnaires, encyclopédies, manuels et autres volumes qui continuent à situer l'expédition de Jean Nicolet dans la région du lac Michigan ${ }^{14}$. Car c'est toujours la biographie de Jean Hamelin, parue en 1966 dans le premier volume du prestigieux Dictionnaire biographique du Canada et inspirée de Sulte, Butterfield, Thwaites et Gosselin, qui semble constituer la référence habituelle sur Jean Nicolet ${ }^{15}$.

Le moins qu'on puisse dire, c'est que les 18 lignes de texte et les 30 lignes de note consacrées à Jean Nicolet par John G. Shea ont eu une portée dépassant toutes ses espérances...

14. Jacques Gagnon, «Mais où est donc passé Jean Nicolet?», Journal of Eastern Townships Studies - Revue d'études des Cantons de l'Est, 8 (printemps 1996): 63-73; «Jean Nicolet au lac Supérieur: essai de datation», Cap-aux-Diamants, 46 (été 1996): 57.

15. Jean Hamelin, «Nicollet de Belleborne, Jean», Dictionnaire biographique du Canada (Québec/Toronto, Presses de l'Université Laval/University of Toronto Press, 1966), I: 527-529. 